\title{
Menanamkan Karakter Gemar Membaca Pada Anak Melalui Gerakan Literasi Sekolah (GLS) di SD Negeri 131 Kota Jambi
}

\author{
Dwi Pujiastuti, Raudhoh \\ Fakultas Adab, Universitas Islam Negeri Sultan Thaha Saifuddin Jambi \\ Jalan Jambi - Muaro Bulian Km. 16, Muaro Jambi, 36363 \\ e-mail:dwipujiastuti560@gmail.com
}

\begin{abstract}
Introduction. Based on the results of the TIMSS and PIRLS survey obtained that the literacy ability of Indonesian students is in a state of concern, so one of the efforts made by the Indonesian government through the Ministry of Education and Culture is by issating the School Literacy Movement (GLS). The School Literacy Movement is an effort made thoroughly to make the school as a learning organization whose citizens are literate throughout life through public involvement. The lack of awareness of students to read results in the urgency of literacy needing to be instilled from elementary school age.

Research Method. This study used descriptive qualitative methods with the determination of the subject purposive sampling.

Result and Discussion. The results showed that SD Negeri 131 Kota Jambi has a GLS strategy in instilling reading character that is done through three (3) stages, namely the habituation stage, development and learning stages. At the habituation stage to familiarize children to read without a bill, the development stage to form reading interests with non-academic bills and the learning stage with academic bills. The impact of GLS strategy in instilling the character of reading in students in State Elementary School 131 can be said that GLS activities begin to instill a favorite or penchant for reading seen from the feeling of pleasure to read, the need for students to read, the desire to always read, the act of finding reading and follow-up. Supporting factors in the implementation of GLS are the active role of all school residents, educator training, the role of parents of students in the form of book donation and involvement in literacy activities and support from outside parties, namely Tanoto foundation, mobile library and student participation in the Evergreen Reading House program. An inhibitory factor is the absence of a dedicated space for libraries as well as different students' reading interests. Efforts to overcome these obstacles are to make a corner of the library as a temporary replacement for the library and make reading angles in each class and the need for commitment of all parties in running literacy programs.
\end{abstract}

Keywords: School Literacy Movement, Character Like Reading

\begin{abstract}
ABSTRAK
Pendahuluan. Berdasakan hasil survei TIMSS dan PIRLS didapat bahwa kemampuan literasi siswa Indonesia berada dalam kondisi memprihatinkan, sehingga salah satu upaya yang dilakukan oleh pemerintah Indonesia melalui Kementerian Pendidikan dan Kebudayaan ialah dengan dikeluarkan Gerakan Literasi Sekolah (GLS). Gerakan Literasi Sekolah merupakan sebuah upaya yang dilakukan secara menyeluruh untuk menjadikan sekolah sebagai organisasi pembelajaran yang warganya literat sepanjang hayat melalui pelibatan publik. Kurangnya kesadaran siswa untuk membaca mengakibatkan urgensi literasi perlu ditanamkan sejak usia sekolah dasar.
\end{abstract}


Metode Penelitian. Penelitian ini menggunakan metode kualitatif deskriptif dengan penentuan subjeknya purposive sampling.

Hasil Penelitian. Hasil penelitian menunjukkan bahwa SD Negeri 131 Kota Jambi memiliki strategi GLS dalam menanamkan karakter gemar membaca yang dilakukan melalui tiga (3) tahapan yakni tahap pembiasaan, tahap pengembangan dan pembelajaran. Pada tahap pembiasaan guna membiasakan anak untuk membaca tanpa disertai tagihan, tahap pengembangan guna membentuk minat baca dengan adanya tagihan non-akademik dan tahap pembelajaran dengan adanya tagihan akademik. Dampak dari strategi GLS dalam menanamkan karakter gemar membaca pada siswa di SD Negeri 131 dapat dikatakan bahwa kegiatan GLS mulai menanamkan kesukaan atau kegemaran siswa untuk membaca yang dilihat dari perasaaan senang terhadap bacaan, kebutuhan siswa untuk membaca, keinginan untuk selalu membaca, tindakan mencari bacaan dan tindak lanjut. Faktor pendukung dalam pelaksanaan GLS ialah peran aktif seluruh warga sekolah, pelatihan tenaga pendidik, peran orangtua siswa berupa donasi buku dan keterliban dalam kegiatan literasi serta dukungan dari pihak luar yakni Tanoto foundation, perpustakaan keliling dan keikutsertaan siswa dalam program Rumah Baca Evergreen. Faktor penghambat ialah tidak adanya ruang khusus untuk perpustakaan serta minat baca siswa yang berbeda. Upaya mengatasi hambatan tersebut ialah membuat pojok perpustakaan sebagai pengganti sementara dari perpustakaan serta membuat sudut baca pada tiap-tiap kelas dan perlunya komitmen semua pihak dalam menjalankan program literasi.

Kata Kunci: Gerakan Literasi Sekolah (GLS); Karakter Gemar Membaca;

\section{A. PENDAHULUAN}

Salah satu indikator yang menjadi tolak ukur tingkat kemajuan suatu bangsa adalah membaca. Suatu negara dapat dikatakan memiliki tingkat budaya yang tinggi apabila semakin banyak waktu yang dimiliki oleh warganya untuk membaca. Bahkan di beberapa Negara, seperti Swedia, Jerman Barat, Amerika Serikat dan Jepang, waktu bisa berarti membaca (Nurhadi, 2016:57).

Berdasarkan penelitian ASEAN Libraries (dalam Meity \& Izul, 2015:29), umumnya masyarakat yang berada di negara-negara berkembang masih kental dengan budaya mengobrol dibandingkan budaya membaca. Termasuk salah satunya ialah bangsa Indonesia yang hingga saat ini merupakan bangsa yang lebih suka bertutur kata (menggunakan budaya lisan). Bahkan seiring dengan perkembangan teknologi yang semakin maju pesat dan tidak terbendung seperti sekarang ini menjadikan budaya lisan masyarakat Indonesia bertransformasi menjadi budaya menonton dan melihat.

Berdasarkan hasil penelitian perpustakaan nasional tahun 2017 (dalam Moh. Nadlir, 2018:Kompas) menunjukkan fakta bahwa rata-rata orang Indonesia membaca buku 3-4 kali per minggu, dengan durasi waktu membaca per hari rata-rata 30-59 menit dengan jumlah buku yang ditamatkan per tahun rata-rata hanya 5-9 buku. 
Terlebih lagi suatu penelitian dari United Nations Educational, Science, and Cultural Organization (UNESCO) menyebutkan bahwa perbandingan antara orang yang minat membaca dengan yang tidak adalah 1:1.000, hal ini didasarkan pada indeks minat baca yang berkisar pada angka 0.001. Perlu digaris bawahi, data ini hanya menyebutkan minat baca. Belum tentu satu orang tersebut gemar membaca apalagi menjadikannya budaya dan belum tentu bacaan yang dibacanya adalah tulisan-tulisan berkualitas. Serupa dengan hal tersebut, berdasarkan studi "Most Littered Nation in The World" yang dilakukan oleh Central Connecticut State University pada maret 2016, Indonesia menduduki peringkat buncit, peringkat 60 dari 61 negara mengenai minat baca (dalam Galuh \& Irwansyah, 2018:13). Dari data-data di atas semakin menegaskan bahwa minat membaca di Indonesia masih tergolong rendah. Padahal agar dapat menjadi suatu kaum intelektual yang dapat menghasilkan karya yang berkualitas budaya membaca ini perlu ditanamkan sedini mungkin.

Adapun mengenai kemampuan literasi siswa Indonesia, hasil survey juga menunjukkan hasil yang memprihatinkan. Hal ini sesuai dengan yang diungkapkan oleh Yunus Abidin dkk (2018:v) yang menyatakan bahwa kemampuan literasi siswa Indonesia sampai saat ini masih sangat memprihatinkan. Hal ini disebabkan oleh kenyataan sejak tahun 2000 kemampuan literasi membaca, literasi sains, dan literasi matematika siswa Indonesia masih rendah jika dibandingkan dengan siswa negara lain. Dari survei yang dilakukan TIMSS dan PIRLS yang dilakukan pada tahun 2011, siswa sekolah dasar di Indonesia masih menempati urutan bawah dibandingkan negara lain. Hasil pengukuran yang dilakukan PISA pada tahun 2016 terhadap kemampuan ketiga jenis literasi tersebut pada siswa jenjang SMP juga menunjukkan hasil yang sama, yakni bahwa kemampuan siswa Indonesia masih menempati posisi bawah di antara seluruh negara yang diukur.

Menanggapi hasil survei terhadap kemampuan literasi siswa Indonesia, salah satu upaya yang dilakukan oleh pemerintah Indonesia melalui Kementerian Pendidikan dan Kebudayaan ialah dengan dikeluarkannya program Gerakan Literasi Nasional yang terdiri atas Gerakan Literasi Sekolah (GLS), Gerakan Literasi Keluarga dan Gerakan Literasi Masyarakat. Gerakan Literasi Nasional dapat mendorong tumbuhnya budaya baca, salah satunya dapat dipantau melalui penyelenggaraan GLS (Lukman Solihin dkk, 2019:2-3). 
Pendidikan karakter merupakan suatu proses yang digunakan untuk membentuk individu yang berkarakter atau berkepribadian. Pendidikan karakter kini marak dilakukan di sekolah-sekolah baik melalui literasi hingga diimplementasikan ke dalam pembelajaran. Selain di sekolah karakter juga harus ditanamkan di lingkungan keluarga dan masyarakat. Salah satu karakter yang perlu dikembangkan adalah karakter gemar membaca. Nilai karakter gemar membaca sangatlah penting bagi kehidupan manusia, agar muncul nilai-nilai karakter yang baik lainnya. Pentingnya GLS (Gerakan Literasi Sekolah) dalam menanamkan karakter gemar membaca didasarkan pada alasan, bahwa banyaknya siswa yang kurang antusias perihal membaca. Adanya perilaku yang belum sesuai tersebut menunjukkan bahwa belum adanya kesadaran siswa di sekolah untuk meningkatkan karakter gemar membaca (Choiri Bayu Respati, 2018:2).

Karakter gemar membaca perlu ditanamkan agar semakin menciptakan masyarakat yang literat yang siap untuk berkarya dan bersaing di Era Pasar Bebas ini, oleh karena itu Gerakan Literasi Sekolah harus diterapkan dan dilestarikan di tiap-tiap sekolah yang ada di Jambi khususnya.

Sekolah merupakan suatu tempat yang memiliki peran penting dalam pelaksanaan program literasi bagi murid-muridnya. Dalam proses pendidikan yang dilaksanakan di sekolah, perlu kiranya bagi pihak sekolah untuk menanamkan budaya literasi yang kuat bagi para siswa sehingga dapat melahirkan generasi kokoh dalam kepribadiannya serta berkualitas.

Gerakan Literasi Sekolah ini memperkuat gerakan penumbuhan budi pekerti sebagaimana dituangkan dalam Peraturan Menteri Pendidikan dan Kebudayaan Nomor 23 Tahun 2015. Salah satu program di dalam GLS ialah kegiatan 15 menit membaca buku non pelajaran sebelum waktu belajar dimulai (Nindya Faradina, 2017:61).

Pangesti Wiedarti dkk (2016:26) menyatakan bahwa program GLS dilaksanakan secara bertahap dengan mempertimbangkan kesiapan sekolah di seluruh Indonesia. Kesiapan ini mencakup kesiapan kapasitas sekolah (ketersediaan fasilitas, bahan bacaan, sarana dan prasarana literasi), kesiapan warga sekolah, dan kesiapan sistem pendukung lainnya (partisipasi publik, dukungan kelembagaan, dan perangkat kebijakan yang relevan). 
SD Negeri 131 Kota Jambi merupakan salah satu dari sekolah dasar yang telah melakukan Gerakan Literasi Sekolah (GLS). Berdasarkan wawancara awal ditemukan bahwasanya SD Negeri 131 Kota Jambi telah melakukan kegiatan literasi sekolah dalam menanamkan kegemaran membaca pada peserta didik melalui kegiatan 15 menit membaca di awal pembelajaran, kegiatan kamis literasi serta pembuatan sudut baca pada tiap-tiap kelas. Namun, terdapat masalah dalam pelaksanaan program GLS di SD Negeri 131 Kota Jambi berkaitan dengan saranaprasarana yakni keterbatasan ruang yang ada menjadikan SD Negeri 131 Kota Jambi tidak memiliki ruang khusus untuk perpustakaan. Pada SD Negeri 131 Kota Jambi hanya memiliki tempat semacam pojok perpustakaan (Wawancara Bersama Ibu Ratumas Atiah, Januari 2020).

Padahal, demi keberhasilan dan kelancaran program Gerakan Literasi Sekolah dibutuhkan dukungan berkaitan dengan sarana prasarana, sesuai dengan tahap awal dalam pelaksanaan pembiasaan Gerakan Literasi Sekolah yaitu pembiasaan berkaitan dengan membangun lingkungan fisik sekolah yang kaya literasi, salah satunya ialah menyediakan perpustakaan sekolah, sudut baca, dan area baca yang nyaman (Pangesti Wiedarti dkk, 2016:29). Salah satu unsur utama dalam program Gerakan Literasi Sekolah ialah keberadaan perpustakaan sekolah sebagai penyedia bahan bacaan utama bagi pendidik dan peserta didik demi kelancaran program GLS.

Sesuai dengan apa yang telah disebutkan sebelumnya bahwa SD Negeri 131 Kota Jambi tidak memiliki perpustakaan sekolah yang sesuai dengan standar yang telah ditetapkan, tetapi fakta di lapangan membuktikan bahwa program GLS di SD Negeri 131 Kota Jambi dapat berjalan walaupun tanpa adanya perpustakaan. Dalam pelaksanaan program GLS seperti 15 menit membaca buku sebelum pelajaran dimulai diperlukan bahan bacaan terutama non-pelajaran dan tentunya perpustakaan sebagai penyedia bahan bacaan tersebut. Lalu bagaimana GLS dapat terus berjalan sedangkan tidak memiliki perpustakaan? Walaupun sekolah telah menyediakan alternative ataupun solusi dengan adanya pojok perpustakaan ataupun sudut baca pada tiap-tiap kelas, namun pertanyaan lain yang muncul ialah darimana buku-buku yang ada pada sudut baca tersebut diperoleh oleh sekolah? Apakah ada sumbangan dari pihak-pihak lain? Jikalau ada, siapa pihak yang berhak menerima buku tersebut sedangkan perpustakaan sebagai wadah tidak ada? Oleh karena itu, peneliti merasa 
perlu untuk mengkaji lebih dalam tentang pelaksanaan GLS di SD Negeri 131 Kota Jambi. Adapun tujuan penelitian ini adalah untuk mengetahui:

a. Strategi GLS dalam menanamkan karakter gemar membaca pada siswa di SD Negeri 131 Kota Jambi

b. Dampak adanya strategi GLS dalam menanamkan karakter gemar membaca pada siswa di SD Negeri 131 Kota Jambi

c. Faktor pendukung dan penghambat strategi GLS dalam menanamkan karakter gemar membaca pada siswa di SD Negeri 131 Kota Jambi

\section{B. TINJAUAN PUSTAKA}

\section{Pengertian Gerakan Literasi Sekolah}

Gerakan Literasi Sekolah (GLS) merupakan sebuah upaya yang dilakukan secara menyeluruh untuk menjadikan sekolah sebagai organisasi pembelajaran yang warganya literat sepanjang hayat melalui pelibatan publik (Dewi Utama Faizah dkk, 2016:2).

Kementerian Pendidikan dan Kebudayaan (dalam Yunus Abidin dkk, 2018:279) menyatakan bahwa GLS merupakan merupakan suatu usaha atau kegiatan yang bersifat partisipatif dengan melibatkan warga sekolah (peserta didik, guru, kepala sekolah, tenaga kependidikan, pengawas sekolah, komite sekolah, orang tua/wali murid peserta didik), akademisi, penerbit, media massa, masyarakat (tokoh masyarakat yang dapat merepresentasikan keteladanan, dunia usaha, dll.), dan pemangku kepentingan di bawah koordinasi Direktorat Jenderal Pendidikan Dasar dan Menengah Kementerian Pendidikan dan Kebudayaan. Lebih lanjut, Pangesti Wiedarti dkk (2016:7) menyatakan bahwa GLS adalah gerakan sosial dengan dukungan kolaboratif berbagai elemen. Upaya yang ditempuh untuk mewujudkannya berupa pembiasaan membaca peserta didik. Pembiasaan ini dilakukan dengan kegiatan 15 menit membaca (guru membacakan buku dan warga sekolah membaca dalam hati, yang disesuaikan dengan konteks atau target sekolah). Ketika pembiasaan membaca terbentuk, selanjutnya akan diarahkan ke tahap pengembangan, dan pembelajaran (disertai tagihan berdasarkan Kurikulum 2013). 
Berdasarkan pendapat di atas, maka dapat disimpulkan bahwa gerakan literasi sekolah (GLS) adalah suatu gerakan literasi yang melibatkan seluruh warga sekolah serta partisipasi publik yang dalam pelaksanaannya memiliki tahapantahapan tertentu dengan tujuan menjadikan warganya literat sepanjang hayat.

\section{Tahapan Pelaksanaan GLS}

Menurut Pangesti Wiedarti, Dkk (2016:29), fokus kegiatan GLS dapat dilihat sebagai berikut:

a. Tahap pembiasaan (belum ada tagihan)

1) Lima belas menit membaca setiap hari sebelum jam pelajaran melalui kegiatan membacakan buku dengan nyaring (read aloud) atau seluruh warga sekolah membaca dalam hati (sustained silent reading).

2) Membangun lingkungan fisik sekolah yang kaya literasi, antara lain: (a) menyediakan perpustakaan sekolah, sudut baca, dan area baca yang nyaman; (b) pengembangan sarana lain (UKS, kantin, kebun sekolah); dan (c) penyediaan koleksi teks cetak, visual, digital, maupun multimodal yang mudah diakses oleh seluruh warga sekolah; (d) pembuatan bahan kaya teks (print rich materials).

b. Tahap pengembangan (ada tagihan sederhana untuk penilaian non-akademik)

1) Lima belas menit membaca setiap hari sebelum jam pelajaran melalui kegiatan membacakan buku dengan nyaring, membaca dalam hati, membaca bersama, dan/atau membaca terpandu diikuti kegiatan lain dengan tagihan non-akademik, contoh: membuat peta cerita (story map), menggunakan graphic organizers, bincang buku.

2) Mengembangkan lingkungan fisik, sosial, afektif sekolah yang kaya literasi dan menciptakan ekosistem sekolah yang menghargai keterbukaan dan kegemaran terhadap pengetahuan dengan berbagai kegiatan, antara lain: (a) memberikan penghargaan kepada capaian perilaku positif, kepedulian sosial, dan semangat belajar peserta didik; penghargaan ini dapat dilakukan pada setiap upacara bendera hari Senin dan/atau peringatan lain; (b) kegiatan-kegiatan akademik lain yang mendukung terciptanya budaya literasi di sekolah (belajar di kebun sekolah, belajar di lingkungan luar 
sekolah, wisata perpustakaan kota/daerah dan taman bacaan masyarakat, dan lain-lain.)

3) Pengembangan kemampuan literasi melalui kegiatan di perpustakaan sekolah/perpustakaan kota/daerah atau taman bacaan masyarakat atau sudut baca kelas dengan berbagai kegiatan, antara lain: (a) membacakan buku dengan nyaring, membaca dalam hati membaca bersama (shared reading), membaca terpandu (guided reading), menonton film pendek, dan/atau membaca teks visual/digital (materi dari internet); (b) peserta didik merespon teks (cetak/visual/digital), fiksi dan nonfiksi, melalui beberapa kegiatan sederhana seperti menggambar, membuat peta konsep, berdiskusi, dan berbincang tentang buku.

c. Tahap pembelajaran (ada tagihan akademik)

1) Lima belas menit membaca setiap hari sebelum jam pelajaran melalui kegiatan membacakan buku dengan nyaring, membaca dalam hati, membaca bersama, dan/atau membaca terpandu diikuti kegiatan lain dengan tagihan non-akademik dan akademik.

2) Kegiatan literasi dalam pembelajaran, disesuaikan dengan tagihan akademik di kurikulum 2013.

3) Melaksanakan berbagai strategi untuk memahami teks dalam semua mata pelajaran (misalnya, dengan menggunakan graphic organizers).

4) Menggunakan lingkungan fisik, sosial afektif, dan akademik disertai beragam bacaan (cetak, visual, auditori, digital) yang kaya literasi di luar buku teks pelajaran untuk memperkaya pengetahuan dalam mata pelajaran

\section{GLS dalam Menanamkan Karakter Gemar Membaca}

Gemar membaca ialah salah satu nilai pendidikan karakter yang dikembangkan di Indonesia. Karakter "Gemar Membaca” berasal dari kata "gemar" dan "baca". Kegemaran membaca (reading habit) didefinisikan oleh American Library Association (ALA) sebagai terbentuknya keinginan yang kuat untuk membaca sepanjang hidup seseorang. Dimana aktivitas membaca sudah menjadi bagian yang tidak terpisahkan dari kehidupan sehari-hari seseorang (Ary Oktarina, 2018:2943). 
Melalui kegiatan sekolah akan tercipta sikap, kepribadian dan karakter siswa. Seperti yang dikatakan Ki Hajar dewantara (dalam Ary Oktarina, 2018), bahwa pendidikan merupakan upaya menumbuhkan budi pekerti (karakter), pikiran (intelek) dan tubuh anak. Implementasi karakter gemar membaca dapat dilakukan dengan gerakan literasi sekolah dengan kegiatan pembiasaan membaca dan pengembangan dalam pembelajaran sekolah.

Melalui tahap pembiasaan maka siswa akan dilatih dan dibiasakan untuk membaca khususnya melalui kegiatan membaca buku non pelajaran selama lima belas menit sebelum pelajaran dimulai. Setelah siswa terbiasa, maka dilanjutkan kepada tahap selanjutnya ialah tahap pengembangan. Pada tahap ini, siswa yang telah terbiasa melakukan kegiatan membaca maka akan dikembangkan menjadi minat baca sehingga dapat tertanam dalam diri siswa karakter gemar membaca (Afifi Renggiwur, Prosiding Seminar Nasional Biologi VI:72).

Kemudian, gemar membaca dapat ditanamkan dengan keberadaan perpustakaan yang membuat siswa nyaman untuk membaca, seperti dengan penjaga yang ramah, dan koleksi buku yang sesuai perkembangan siswa (Ary Oktarina, 2018).

Menurut Burs dan Lowe (dalam Rofiqul Khasanah, 2015:27) tentang indikatorindikator adanya minat membaca pada seseorang, yaitu: a) rasa senang terhadap membaca, b) Kebutuhan terhadap bacaan, c) Keinginan untuk selalu membaca, d) Tindakan mencari bacaan, e)Tindak lanjut (menindaklanjuti dari apa yang dibacanya)

Ibrahim Bafadhal menyatakan bahwa rasa senang membaca dapat disebabkan oleh beberapa faktor, yaitu: karena ia tahu manfaat membaca, ia menyadari bahwa buku-buku dan bahan pustaka lainnya yang baik dapat memperluas pengetahuannya (Rofiqul Khasanah, 2015:27).

Sebagai perbanding penelitian lain yang dapat dijadikan sebagai studi relevan peneliti adalah:

1. Gerakan Literasi dalam Upaya Membentuk Perilaku Budaya Baca di SDN 58/X Tanjung Jabung Timur. Penelitian ini dilakukan oleh Wahyu Kurniawan pada tahun 2017. Persamaan pada penelitian ini dengan penelitian penulis yaitu judul yang diangkat mengenai GLS dalam membentuk prilaku budaya baca, dalam hal 
ini penulis menggunakan istilah karakter gemar membaca. Sama-sama menggunakan teori GLS yang terbagi atas tiga (3) tahap dengan jenis penelitian kualitatif deskriptif, dan teknik purposive sampling. Perbedaannya yaitu dalam rumusan masalah penelitian penulis menambahkan dampak strategi GLS dalam menanamkan karakter gemar membaca, serta perbedaan dalam penulisan hasil penelitian dimana peneliti ini menyusun berdasarkan program sedangkan penelitian penulis disusun berdasarkan tiga (3) tahapan GLS.

2. Implementasi Gerakan Literasi Sekolah (GLS) di MI Negeri Kota Semarang Tahun Ajaran 2018/2019. Penelitian dilakukan oleh Nulul Azmi pada tahun 2019. Persamaan pada penelitian ini dengan penelitian penulis yaitu sama-sama menggunakan teori GLS yang terbagi atas tiga (3) tahap dengan jenis penelitian kualitatif deskriptif, dan teknik purposive sampling. Kemudian, adanya kesamaan pada hasil penelitian pada beberapa poin di faktor pendukung dan penghambat serta solusi mengatasinya. Perbedaannya yaitu dalam rumusan masalah penelitian penulis menambahkan dampak strategi GLS dalam menanamkan karakter gemar membaca, serta perbedaan dalam penulisan hasil penelitian dimana peneliti ini menyusun berdasarkan program sedangkan penelitian penulis disusun berdasarkan tiga (3) tahapan GLS.

\section{METODE PENELITIAN}

Penelitian ini menggunakan jenis penelitian deskriptif dengan pendekatan kualitatif. Adapun alasan menggunakan kualitatif deskriptif dikarenakan data yang diperoleh tidak dapat dihitung secara matematis karena berwujud kata-kata dan data yang telah terkumpul disajikan secara alamiah (apa adanya).

Lokasi penelitian ini dilakukan di SD Negeri 131 Kota Jambi yang bertempat di Jl. Kapt. A. Khatib, RT 14, Pematang Sulur, Kecamatan Telanaipura, Kota Jambi. Dipilihnya tempat ini sebagai lokasi penelitian didasarkan pada alasan; pertama, SD Negeri 131 Kota Jambi merupakan sekolah yang menerapkan program khusus GLS Kamis Literasi. Alasan kedua, merupakan salah satu SD Negeri di Kota Jambi yang merupakan mitra Tanoto Foundation dengan sebagian besar gurunya terlibat aktif di dalamnya dan alasan ketiga SD Negeri 131 Kota Jambi merupakan sekolah yang terakreditasi A. 
Subjek penelitian adalah individu, benda atau organisme yang dijadikan sumber informasi yang dibutuhkan dalam pengumpulan data penelitian (Idrus, 2009:91). Penentuan subjek penelitian ini menggunakan teknik purposive sampling, dengan informan kunci ialah kepala sekolah dan informan lainnya adalah para guru serta beberapa orang siswa yang dipilih berdasarkan kriteria; (1) rekomendasi wali kelas, (2) memiliki kegemaran terhadap membaca.

Sumber data dalam penelitian kualitatif ialah kata-kata dan tindakan selebihnya adalah data tambahan seperti dokumen dan lain-lain (Rosady Ruslan, 2006). Berdasarkan sumber data, maka prosedur pengumpulan data dilakukan dengan menggunakan: (1) wawancara mendalam berstruktur, (2) observasi terus terang atau tersamar, dan (3) dokumentasi meliputi: profil SD Negeri 131 Kota Jambi, saranaprasarana GLS, dokumentasi penting lainnya seperti daftar koleksi hibah dari Tanoto Foundation.

Analisa data dalam penelitian kualitatif dilakukan pada saat pengumpulan data berlangsung, dan setelah data selesai pengumpulan data dalam periode tertentu. Pada saat wawancara, peneliti sudah melakukan analisis terhadap jawaban yang diwawancarai. Bila jawaban yang diwawancarai setelah dianalisis terasa belum memuaskan, maka peneliti akan melanjutkan pertanyaan lagi sampai pada tahap tertentu data yang diperoleh dianggap kredibel. Adapun analisa data pada penelitian ini melalui beberapa komponen, yaitu: reduksi data, penyajian data dan penarikan kesimpulan (Sugiyono, 2016:246).

Dalam penelitian ini, untuk menguji keabsahan data maka peneliti menggunakan triangulasi teknik. Dalam triangulasi teknik, untuk menguji kredibilitas data dilakukan dengan cara mengecek data kepada sumber yang sama dengan teknik yang berbeda (Sugiyono, 2016:274).

\section{HASIL DAN PEMBAHASAN}

\section{Strategi Gerakan Literasi Sekolah (GLS) dalam Menanamkan Karakter} Gemar Membaca pada Siswa di Sekolah Dasar Negeri 131 Kota Jambi

Gerakan literasi sekolah (GLS) yang ada di SD Negeri 131 Kota Jambi sudah terlaksana sejak tahun 2015. Dalam pelaksanaan GLS di SD Negeri 131 Kota Jambi memiliki Tim Gerakan Literasi Sekolah dengan Basyir, S.Pd sebagai penanggung jawab, Ratumas Atiah, S.Pd sebagai ketua, Namela Wirawan, S.Pd sebagai sekretaris 
serta Nurfaidah, S.Pd sebagai penyelaras kualitas materi. Telah diketahui bahwa SDN. 131 Kota Jambi tidak memiliki ruang khusus untuk perpustakaan, namun SDN. 131 Kota Jambi tetap berupaya untuk menjalankan GLS. Dalam strategi GLS, maka kegiatan yang dilakukan SDN. 131 Kota Jambi dalam menanamkan karakter gemar membaca pada siswa dapat dilihat dari tahapan pelaksaanan GLS yang terbagi atas tiga tahapan yakni: tahap pembiasaan, tahap pengembangan dan tahap pembelajaran.

\section{1) Tahap Pembiasaan}

Sesuai dengan Permendikbud Nomor 23 Tahun 2015 maka pihak sekolah melakukan pelaksanaan literasi yakni pemberlakuan kegiatan 15 menit membaca sebelum pelajaran dimulai yang diberlakukan di setiap kelas. Dalam pelaksanaannya dilakukan dengan membaca secara nyaring maupun dalam hati. Pada siswa kelas rendah, maka terdapat kegiatan membaca terbimbing dengan menggunakan Big Book. Berdasarkan observasi dan wawancara dengan para guru, maka didapat bahwa untuk mendukung kegiatan literasi dalam menanamkan kebiasaan gemar membaca pada siswa, maka pihak sekolah membuat waktu khusus literasi yang dinamakan Kamis Literasi. Program Kamis literasi ini terbentuk sebagai hasil dari pelatihan yang dilakukan oleh Tanoto Foundation tentang Budaya Baca. Dalam kegiatan kamis literasi diawali dengan membaca senyap selama 15 menit kemudian dilanjutkan dengan tahap pengembangan yakni menceritakan kembali apa yang telah dibaca dengan gaya bahasa sendiri.

Pada tahap ini, GLS bertujuan untuk menumbuhkan minat terhadap bacaan dan terhadap kegiatan membaca dalam diri warga sekolah (Pangesti Wiedarti dkk, 2016). Adapun strategi GLS yang dilakukan oleh pihak sekolah ialah dengan membangun lingkungan fisik sekolah yang kaya literasi. Pada SD Negeri 131 Kota Jambi, pihak sekolah menyediakan pojok perpustakaan, sudut baca pada tiap-tiap kelas yang bukunya disesuaikan dengan usia dan jenjang kelas atau minat siswa serta pembuatan bahan kaya teks seperti hasil karya siswa yang kemudian diletakkan pada mading. Untuk koleksi yang ada di pojok perpustakaan sebagian merupakan pinjaman dari perpustakaan wilayah dan hibah dari Tanoto Foundation yang kemudian disebar ke sudut baca pada tiap-tiap kelas. Kemudian, koleksi yang ada di sudut baca sebagian berasal dari donasi orang tua wali murid. 
Saat dimasa COVID-19, maka kegiatan membaca yang dilakukan ialah dengan pemberian tugas oleh guru untuk membaca di rumah (wawancara bersama wali kelas, 2021).

\section{2) Tahap Pengembangan}

Kegiatan pada tahap pengembangan, pada prinsipnya sama dengan kegiatan pada tahap pembiasaan. Pada tahap ini buku yang siswa baca masih berdasarkan kesenangan atau minat peserta didik. Adapun yang menjadi perbedaan dengan kegiatan pada tahap pembiasaan ialah adanya tindak lanjut dari apa yang telah dibaca baik dalam bentuk lisan maupun tulisan. Pada SD Negeri 131 Kota Jambi, setelah kegiatan 15 menit membaca sebelum jam pelajaran tindak lanjut yang dilakukan ialah dengan merangkum apa yang telah dibaca dan atau menceritakan apa yang telah dibaca di depan kelas. Berdasarkan observasi dan wawancara dengan wali kelas, terdapat pohon literasi yang berfungsi untuk menempel hasil dari apa yang telah siswa baca yakni berisi nama siswa, judul bacaan, serta sinopsis cerita yang telah mereka baca.

Pada tahap ini, saat 15 menit sebelum pembelajaran dimulai maka terkadang guru yang membacakan buku misalnya Big Book. Untuk prosedur pelaksanaan kegiatan membaca Big Book tidak sama dengan membaca buku biasa. Dalam pembacaan buku Big Book tergantung dari jumlah katanya. Untuk kelas rendah suku katanya masih beberapa sekitar 10 kata, terutama di kelas 1. Untuk kelas tinggi suku katanya lebih banyak, yang mana tujuan dari dibacakannya Big Book ini ada empat (4) fokus, yaitu fokus pediksi dari buku itu, kata-kata sulit, tanda baca dan pemahaman. Bagi siswa tingkat rendah, maka kegiatan yang dilakukan ialah mengamati gambar di Big Book serta membaca bersama. Adapun setelah mengamati gambar di Big Book kemudian ada tagihan non-akademik berupa tulisan mengenai apa yang telah diamati. Tindak lanjut pada masa COVID-19 ialah dengan meminta siswa untuk memvideokan buku yang telah dibaca secara lisan via whatsapp.

Pada tahap ini, terdapat kegiatan akademik lain yang mendukung terciptanya budaya literasi di sekolah seperti adanya wisata ke perpustakaan kota dan gramedia serta kunjungan dari perpustakaan keliling sesuai dengan jadwal. 
Dalam pengembangan kemampuan literasi di SD Negeri 131 Kota Jambi dilakukan melalui kegiatan di sudut baca kelas terkait aktivitas memperkenalkan jenis bacaan kepada siswa serta menggunakan sudut baca untuk membaca secara senyap di jam pelajaran tertentu seperti bahasa Indonesia. Adapun dalam kegiatan ini tujuannya selain untuk meningkatkan literasi perpustakaan siswa juga untuk mengembangkan literasi siswa terkait dengan membaca, menulis dan mengkomunikasikan apa yang telah dibaca.

\section{3) Tahap Pembelajaran}

Dalam tahap pembelajaran, kegiatan 15 menit membaca juga dikaitkan dengan pembelajaran yang akan dipelajari. Kegiatan membaca 15 menit di awal maupun di tengah pelajaran yang diikuti dengan tagihan akademik. Namun, pelaksanaannya belum sepenuhnya dilakukan, tergantung dengan kesesuaian materi yang diajar dan tidak semua wali kelas melakukan hal tersebut. Kemudian, guru belum sepenuhnya mensyaratkan siswa untuk membaca buku non pelajaran. Dimana buku yang dibaca oleh siswa berupa buku tentang pengetahuan umum, kegemaran minat khusus, dan juga dapat dikaitkan dengan mata pelajaran tertentu sebanyak 6 buku bagi siswa SD (Pangesti Wiedarti dkk, 2016).

Kegiatan literasi pada tahap ini telah disesuaikan dengan pembelajaran pada Kurikulum 2013 dimana setiap pembelajaran terdapat kegiatan membaca dan menulis. Tagihan atau tugas-tugas yang diberikan juga sesuai dengan Kurikulum 2013 berupa peta pikiran serta pemahaman siswa dalam bentuk kesimpulan dan laporan berkelompok.

Pada SD Negeri 131 Kota Jambi, terdapat strategi membaca bertujuan memudahkan siswa dalam memahami materi. Strategi yang digunakan bagi kelas satu ialah dengan metode ejaan, menggunakan Big Book serta ADeK SiMBa. Kemudian untuk siswa kelas tinggi maka strategi yang digunakan ialah dengan peta pikiran dan ADeK SiMBa $(5 \mathrm{~W}+1 \mathrm{H})$. Pada tahap ini, terdapat pembelajaran di sudut baca dengan kegiatan mencari informasi tertentu dalam suatu bahan bacaan. Adapun kegiatan ini dilakukan oleh siswa kelas tinggi. 
2. Dampak Adanya Strategi Gerakan Literasi Sekolah dalam Menanamkan Karakter Gemar Membaca pada Siswa di SD Negeri 131 Kota Jambi

Gerakan Literasi Sekolah (GLS) merupakan gerakan literasi yang mempunyai tujuan untuk menjadikan siswanya literat sepanjang hayat (Dewi Utama Faizah, 2016:2). Sebagai dampak dari dilakukannya GLS di sekolah ialah menjadikan siswanya memiliki karakter gemar membaca yang tentunya dapat diwujudkan dengan adanya pembiasaan membaca yang dilakukan secara bertahap dan konsisten. Adapun dalam mengukur karakter gemar membaca pada siswa sebagai dampak dari adanya GLS ialah dengan menggunakan indikator gemar membaca menurut Burs dan Lowe sebagai berikut: rasa senang terhadap bacaan, kebutuhan terhadap bacaan, keinginan untuk selalu membaca, tindakan untuk mencari bacaan, serta tindak lanjut (Rofiqul Khasanah, 2015:27).

Berdasarkan hasil wawancara dari beberapa orang siswa, maka siswa memiliki perasaan senang untuk membaca buku pada jam literasi, seperti buku cerita, namun rasa senang siswa untuk membaca juga dipengaruhi oleh mood siswa. Rasa senang membaca siswa merupakan sesuatu yang terbentuk dari adanya pembiasaan yang dilakukan oleh orang terdekat mereka, seperti di sekolah ialah guru. Ketika ditanya apa alasan yang membuat mereka senang membaca, maka sebagian siswa menjawab bahwa rasa senang membaca ini bermula dari adanya pembiasaan membaca yang dilakukan oleh wali kelas atau dalam arti lain bahwa kegiatan literasi berpengaruh terhadap rasa senang mereka untuk membaca. Dalam rasa senang terhadap bacaan, maka siswa memiliki rasa tertarik untuk selalu membaca buku yang sedang mereka baca. Siswa memiliki ketertarikan untuk terus membaca buku yang sedang mereka baca disebabkan jalan ceritanya yang menarik bagi mereka. Kemudian, sebagian siswa menjawab bahwa karena ada manfaat yang didapat setelah membaca, maka timbullah perasaan puas setelah membaca.

Kebutuhan terhadap bacaan apabila dikaitkan dengan istilah literasi maka dapat dilihat dari adanya kebutuhan siswa untuk membaca buku pelajaran dan buku penunjang mata pelajaran lainnya baik atas kemauan sendiri ataupun perintah guru. Kebutuhan siswa terhadap bacaan terlihat dari adanya kesulitan dalam mengerjakan tugas sehingga membuat siswa membuka buku dan membaca untuk mencari jawaban seperti tugas matematika maupun tugas-tugas lainnya (Wawancara, 2021). 
Terkait dengan adanya keinginan untuk selalu membaca, sebagian siswa memiliki keinginan untuk membaca baik ketika disuruh guru maupun tanpa disuruh guru. Dalam memanfaatkan waktu luang maka sebagian siswa mengisinya dengan membaca buku, dimana siswa bermain ataupun membeli makanan terlebih dahulu sebelum membaca buku maupun kegiatan lainnya seperti mengerjakan tugas (Wawancara, 2021).

Keinginan untuk selalu membaca mengakibatkan adanya tindakan untuk mencari bacaan. Adapun bentuk tindakan yang dilakukan oleh siswa terlihat dari adanya siswa yang mengunjungi pojok perpustakaan maupun sudut baca kelas. Berdasarkan wawancara, tindakan siswa ini dipengaruhi karena adanya pembiasaan untuk membaca di sudut baca bagi yang telah menyelesaikan tugas agar tidak mengganggu teman yang belum selesai. Kemudian, didapatkan bahwa siswa juga membeli buku bacaan yang dia sukai, namun ada juga siswa yang pernah mengunjungi toko buku namun tidak untuk membeli buku. Sebagian siswa menuturkan bahwa agar dapat membaca buku yang dinginkan, maka siswa menabung terlebih dahulu sebelum membeli buku walaupun ada juga yang tidak pernah melakukannya. Kemudian terdapat tindakan untuk meminjam buku baik di sudut baca kelas, perpustakaan tempat mereka mengaji maupun di taman bacaan evergreen (Wawancara, 2021).

Berkaitan dengan tindak lanjut ataupun menindaklanjuti dari apa yang telah dibaca maka dilihat dari adanya tindak lanjut siswa untuk menceritakan secara lisan dan secara tulisan dari apa yang telah dibacanya. Namun hal tersebut dilakukan siswa saat jam literasi, sedangkan di luar kegiatan literasi hanya sebagian saja yang melakukannya.

\section{Faktor Pendukung dan Penghambat Strategi Gerakan Literasi Sekolah} (GLS) dalam Menanamkan Karakter Gemar Membaca pada Siswa di SDN

\section{Kota Jambi}

Dalam pelaksanaan GLS di SD Negeri 131 Kota Jambi, yang menjadi faktor pendukung ialah adanya peran aktif seluruh warga sekolah yakni Kepala Sekolah melalui partispasi aktif dalam program GLS yakni ikut serta dalam kegiatan membaca pada saat Kamis Literasi serta terus berupaya untuk menggelorakan 
pentingnya GLS dengan terus menghimbau warga sekolah terutama siswa untuk membudayakan membaca. Kemudian peran guru sebagai agen pelaksana GLS serta siswa sebagai sasaran utama GLS menunjukkan rasa antusias dalam pelaksanaan GLS. Agar guru dapat menjadi teladan dalam hal berliterasi maka perlu namanya penguatan kapasitas fasilitator. Maka, pihak sekolah memberikan kesempatan para guru dengan mengikuti berbagai pelatihan untuk menunjang pemahaman serta kesiapan guru sebagai teladan dalam hal berliterasi. Faktor pendukung lainnya ialah dukungan dari orang tua siswa berupa pemberian donasi dalam bentuk buku untuk koleksi di sudut baca, kerjasama dengan Tanoto Foundation melalui pemberian hibah buku, perpustakaan dengan adanya perpustakaan keliling dan keikutsertaan siswa dalam program Rumah Baca Evergreen.

Namun, dalam pelaksanaannya tidak terlepas dari beberapa kendala yakni dikarenakan keterbatasan ruang yang ada maka SDN. 131 Kota Jambi tidak memiliki ruang khusus untuk perpustakaan. Adapun ruang perpustakaan yang ada telah dijadikan sebagai ruang kelas. Oleh karena itu, untuk mengatasi hal tersebut ialah dengan membangun pojok perpustakaan sebagai pengganti sementara dari perpustakaan serta membuat sudut baca pada tiap-tiap kelas yang bertujuan agar siswa tidak hanya berpusat dengan pojok baca yang tidak terlalu besar. Namun keberadaan perpustakaan tetap diperlukan di setiap sekolah, terutama SD Negeri 131 Kota Jambi. Hal ini dikarenakan walaupun pihak sekolah telah membuat pojok perpustakaan sebagai pengganti perpustakaan, tetapi ruang pojok yang disediakan belumlah cukup dengan jumlah siswa yang memiliki 12 rombongan belajar. Oleh karena itu, pembangunan ruang khusus sebagai perpustakaan merupakan solusi utama dalam mewujudkan generasi yang gemar membaca.

Adapun kendala lainnya ialah tidak semua siswa memiliki kecintaan yang sama dalam membaca, sesuai dengan pernyataan wali kelas yang menyatakan bahwa salah satu penyebabnya karena kurangnya peran orangtua dalam melakukan tindak lanjut dari pembiasaan membaca yang telah dilakukan di sekolah. Sehingga perlu namanya komitmen dari semua pihak untuk melaksanakan GLS dengan sungguh-sungguh. Menanggapi adanya anak yang kurang lancar dalam membaca yang tentu saja menjadi kendala untuk menumbuhkan minat membaca, sesuai dengan pernyataan ibu Nurfaidah, maka ada rencana untuk membuat klinik literasi. Peran orangtua dalam 
menumbuhkan minat baca anak pun sangat penting. Orang tua maupun guru harus dapat memotivasi dengan memberi contoh perilaku gemar membaca, selalu mengingatkan untuk membaca serta memberikan lingkungan yang kaya literasi dengan menyediakan bahan bacaan yang sesuai umur dan minat mereka.

\section{E. KESIMPULAN}

SD Negeri 131 Kota Jambi telah melakukan strategi GLS berkaitan dengan menanamkan karakter gemar membaca pada siswa, yakni melalui tiga (3) tahapan yakni pembiasaan, pengembangan dan pembelajaran. Pada tahap pembiasaan, pihak sekolah memberikan waktu khusus yakni kamis literasi untuk membiasakan siswa membaca serta membangun lingkungan fisik sekolah yang kaya literasi melalui penyediaan pojok perpustakaan, sudut baca tiap kelas. Pada tahap pengembangan dilakukan dengan disertai tagihan non-akademik, namun pihak sekolah belum sepenuhnya memberikan penghargaan bagi siswa secara rutin terutama dalam kaitan literasi. Pada tahap pembelajaran dengan disertai tagihan akademik, namun kegiatan membaca 15 menit di awal maupun di tengah pelajaran yang diikuti dengan tagihan akademik belum sepenuhnya dilakukan, tergantung kepada guru yang mengajar dan kesesuaian materi yang diajar. Kemudian pihak sekolah juga belum sepenuhnya mensyaratkan siswa untuk membaca buku non pelajaran sebanyak 6 buku bagi siswa SD. Kegiatan pembelajaran di sudut baca kelas bagi siswa kelas rendah belum sepenuhnya terlaksana. Dampak dari adanya strategi GLS dapat dilihat dari indikator gemar membaca. Berdasarkan indikator tersebut terlihat bahwa kegiatan GLS mulai menanamkan kesukaan atau kegemaran siswa untuk membaca. Dalam pelaksanaan GLS di SD dapat berjalan dikarenakan adanya berbagai dukungan baik secara internal maupun eksternal. Namun, dalam pelaksanaannya masih terdapat berbagai kendala. 


\section{DAFTAR PUSTAKA}

Afifi Renggiwur. Pengaruh Program Literasi Sekolah Terhadap Minat Membaca dan Hasil Belajar IPA Siswa SMP Negeri Kota Tual. Prosiding Seminar Nasional Biologi VI: Harmonisasi Pembelajaran Biologi pada Era Revolusi 4.0. 71-77 dari ojs.unm.ac.id

Ary Oktarina. (2018). Pendidikan Karakter Gemar Membaca Melalui Program Literasi di SDN Golo Yogyakarta. Jurnal Pendidikan Guru Sekolah Dasar. Tahun Ke-7. Edisi 30. 2941-2942. Yogyakarta

Choiri Bayu Respati. (2018). Implementasi Gerakan Literasi Sekolah dalam Menanamkan Karakter Gemar Membaca Siswa Kelas Tinggi di SD Negeri 1 Sawahan. Naskah publikasi: Universitas Muhammadiyah Surakarta

Dewi Utama Faizah dkk. (2016). Panduan Gerakan Literasi Sekolah di Sekolah Dasar. Jakarta: Kementerian Pendidikan dan Kebudayaan

Galuh Ayu Puspita, \& Irwansyah. (2018). Pergeseran Budaya Baca dan Perkembangan Industri Penerbitan Buku di Indonesia: Studi Kasus Pembaca E-book melalui Aplikasi iPusnas. BIBLIOTIKA: Jurnal Kajian Perpustakaan dan Informasi. Volume 2. Nomor 1. 13-20

Lukman Solihin dkk. (2019). Indeks Aktivitas Literasi Membaca 34 Provinsi. Jakarta: Kementerian Pendidikan dan Kebudayaan

Meity H. Idris, \& Izul Ramdani. (2015). Menumbuhkan Minat Membaca pada Anak Usia Dini. Jakarta: Luxima Metro Media

Moh. Nadlir. (2018). Per Hari, Rata-rata Orang Indonesia Hanya Baca Buku Kurang dari Sejam. (D. Meiliana, Ed.) Retrieved Februari Selasa, 2019, from Kompas.com: https://nasional.kompas.com

Muhammad Idrus. (2009). Metode Penelitian Ilmu Sosial, Pendekatan Kualitatif dan Kuantitaif. Jakarta: Erlangga

Nindya Faradina. (2017). Pengaruh Program Gerakan Literasi Sekolah terhadap Minat Baca Siswa di SD Islam Terpadu Muhammadiyah An-Najah Jatinom Klaten. Jurnal Hanata Widya. Volume 6. Nomor 8. 60-68

Nurhadi. (2016). Strategi Meningkatkan Daya Baca. (N. Syamsiyah, Ed.) Jakarta: Bumi Aksara.

Nur Suci Ramadhani. n.d. Analisis Pelaksanaan Program Gerakan Literasi Sekolah (GLS) di SMP Kota Surabaya. Retrieved Agustus Senin, 2019, from repository.unair.ac.id

Pangesti Wiedarti dkk. (2016). Desain Induk Gerakan Literasi Sekolah. Jakarta: Direktorat Jenderal Pendidikan Dasar dan Menengah Kementerian Pendidikan dan Kebudayaan

Rofiqul Khasanah. (2015). Faktor-Faktor yang Mempengaruhi Minat Membaca Siswa Kelas iv B SD Negeri Ngoto Sewon Bantul Tahun Ajaran 2014-2015. Skripsi. Universitas Negeri Yogyakarta. Yogyakarta

Rosady Ruslan. (2006). Metode Penelitian: public relation dan komunikasi. Jakarta: Raja Grafindo Persada

Sugiyono. (2016). Metode Penelitian: kuantitatif, kualitatif dan $R$ \& D. Bandung: Alfabeta.

Yunus Abidin dkk. (2018). Pembelajaran Literasi: Strategi Meningkatkan Kemampuan Literasi Matematika, Sains, Membaca dan Menulis. Jakarta: Bumi Aksara 